\title{
NILAI DIAGNOSIS DAN PROGNOSIS JUMLAH DAN INDEKS TROMBOSIT, MEAN PLATELET VOLUME (MPV) DAN PLATELETCRIT (PCT) PADA PENDERITA SEPSIS NEONATORUM
}

\author{
M Angelina de Rosari ${ }^{*}$, Agustin Iskandar ${ }^{* \star 凶}$, Saptadi Yuliarto ${ }^{\star * *}$
}

\begin{abstract}
Abstrak
Sepsis neonatorum merupakan penyebab utama kematian pada neonatus di Indonesia. Kondisi ini dapat memicu terjadinya disseminated intravascular coagulation (DIC), lalu meningkatkan konsumsi platelet dan mengakibatkan trombositopenia. Penelitian ini bertujuan untuk mengetahui nilai diagnostik dan prognostik jumlah dan index trombosit, mean platelet volume (MPV) dan plateletcrit (PCT) pada sepsis neonatorum. Penelitan ini adalah penelitian retrospektif menggunakan data sekunder pada neonatus terduga sepsis yang dirawat di RSU dr. Saiful Anwar Malang. Hasil penelitian menunjukkan nilai diagnostik jumlah trombosit adalah sensitivitas $89,3 \%$, spesifisitas $75 \%$, sedangkan MPV sensitivitas $25 \%$ dan spesifisitas $10,7 \%$. Nilai prognostik trombosit untuk menentukan outcome sepsis neonatorum adalah sensitivitas $55,6 \%$ dan spesifisitas $58,3 \%$, sedangkan MPV $33,3 \%$ dan $33,3 \%$. Kadar PCT tidak bisa digunakan baik untuk diagnosis maupun prognosis sepsis neonatorum. Kesimpulan penelitian ini adalah jumlah trombosit mempunyai nilai diagnosis dan prognosis yang lebih baik bila dibandingkan dengan MPV pada sepsis neonatorum. Namun penegakan diagnosis dan prognosis sepsis neonatorum harus tetap ditentukan berdasar pada anamnesa baik terkait faktor risiko maupun riwayat penyakit, gambaran klinis, dan pemeriksaan penunjang.
\end{abstract}

Kata kunci: jumlah dan index trombosit, sepsis neonatorum.

\section{DIAGNOSIS AND PROGNOSIS VALUE INDEX NUMBER AND PLATELETS, MEAN PLATELET VOLUME (MPV) AND PLATELETCRIT (PCT) IN NEONATAL SEPSIS}

\begin{abstract}
Neonatal sepsis is the leading cause of death in neonates in Indonesia. This condition can trigger the occurrence of disseminated intravascular coagulation (DIC), increase platelet consumption and cause thrombocytopenia. This study aimed were to determine the diagnostic and prognostic value of the number and platelet index, mean platelet volume (MPV) dan plateletcrit (PCT) in neonatal sepsis. This was a retrospective study by using secondary data in inpatient of neonatal sepsis at dr. Saiful Anwar General Hospital Malang. The results showed that the diagnostic value of thrombocyte count was $89.3 \%$ sensitivity, $75 \%$ specificity, while the sensitivity of MPV was $25 \%$ and the specificity was $10.7 \%$. The prognostic value of platelets to determine the outcome of neonatal sepsis was sensitivity of $55.6 \%$ and specificity of $58.3 \%$, while MPV $33.3 \%$ and $33.3 \%$. PCT levels did not have value either for the diagnosis or the prognosis of neonatal sepsis. The conclusion of this study is that the number of platelet has a better diagnosis and prognosis value when compared with MPV in neonatal sepsis. However, the diagnosis and prognosis of neonatal sepsis should still be determined based on anamnesis with regard to both risk factors and disease history, clinical features and other investigations.
\end{abstract}

Keywords: neonatal sepsis, platelet count, platelet index.

* Jurusan S1 Pendidikan Dokter, Fakultas Kedokteran Universitas Brawijaya

** Departemen Parasitologi, Fakultas Kedokteran Universitas Brawijaya

${ }^{* * *}$ Departemen IImu Kesehatan Anak, Fakultas Kedokteran Universitas Brawijaya-RSSA Malang

$凶$ E-mail: agustiniskandar52@gmail.com 


\section{Pendahuluan}

Sepsis neonatorum adalah gejala klinik penyakit sistemik, disertai dengan adanya bakteri dalam aliran darah yang terjadi pada bayi dalam satu bulan pertama kehidupan. Sepsis neonatorum merupakan penyebab utama kematian pada neonatus. ${ }^{1}$

Angka kejadian sepsis neonatorum di dunia berkisar antara 1-8 per 1000 kelahiran hidup. Di negara maju seperti Amerika kejadian sepsis sejak 1980 bervariasi di antara 2-4 per 1000 kelahiran hidup, sedangkan di negara berkembang seperti India, angka kejadiannya 34-37 per 1000 kelahiran hidup. Indonesia belum mempunyai data yang pasti tentang kejadian sepsis. Tetapi pada tahun 2009 di Rumah Sakit Cipto Mangunkusumo kejadian sepsis neonatorum

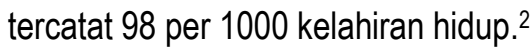

Sepsis neonatorum sampai saat ini masih merupakan keadaan kedaruratan karena keterlambatan pengobatan dapat penyebabkan kematian, sedangkan diagnosis sepsis neonatorum sulit untuk ditegakkan karena gambaran klinis yang tidak spesifik. Diagnosis dini dan penanganan yang tepat dapat menurunkan mortalitas dan morbiditas pada pasien, sehingga pemeriksaan penunjang sangat diperlukan. Pemeriksaan kultur merupakan baku emas dalam penegakan diagnosis pasti sepsis neonatorum, namun pemeriksaan ini membutuhkan waktu 3-5 hari dan seringkali hasilnya adalah negatif. 3,4

Trombosit memiliki banyak fungsi, khususnya dalam mekanisme hemostasis. Fungsinya yaitu mencegah kebocoran darah spontan pada pembuluh darah kecil dengan cara adhesi, sekresi, agregasi, dan fusi (hemostasis). Cara kerja trombosit dalam hemostasis sebagai berikut: adanya pembuluh darah yang mengalami trauma maka akan menyebabkan sel endotel rusak dan terpaparnya jaringan ikat kolagen (subendotel). Lalu trombosit membengkak dan melekat satu sama lain atas bantuan ADP dan tromboksan A2 (proses agregasi). Kemudian dilanjutkan pembentukan kompleks protein pembekuan (prokoagulan). Sampai tahap ini terbentuklah hemostasis yang permanen. Pada suatu saat bekuan ini akan dilisiskan jika jaringan yang rusak telah mengalami perbaikan oleh jaringan yang baru. ${ }^{5,6}$

Trombositemi atau trombositsosis adalah peningkatan jumlah trombosit. Trombositosis reaktif terhadap berbagai penyebab akut dan kronis. Trombositopenia, yang merupakan penyebab gangguan perdarahan yang paling sering ditemukan, adalah keadaan defisiensi trombosit yang beredar di dalam darah. 7,8

Mekanisme trombositopenia pada sepsis neonatorum disebabkan oleh hipoplasia megakariosit, penurunan produksi trombosit akibat splenomegali dan retikulo endothelial sistem dan koagulasi intravaskular diseminata. Prognosis sepsis bakterialis pada neonatus bervariasi, namun dengan adanya trombositopenia angka kematian sepsis neonatorum akan meningkat Pemeriksaan trombosit ini dilakukan dengan mudah dan cepat untuk mendiagnosis sepsis neonatorum karena pada hasil laboratorium keadaan sepsis neonatorum sering ditemukan trombositopenia. ${ }^{9}$

Index trombosit terdiri dari mean platelet volume (MPV) dan plateletcrit PCT. MPV mengukur ukuran trombosit yang beredar dalam darah perifer. Oleh karena trombosit muda berukuran lebih besar, maka MPV yang tinggi merupakan petanda peningkatan produksi trombosit atau mungkin sebagai kompensasi untuk mempercepat penghancuran platelet. ${ }^{10}$

Plateletcrit (PCT) dapat membantu untuk mendiagnosis dan tindak lanjut dari 
sepsis. Rendahnya PCT juga ditemukan pada pasien malaria akut. PCT merupakan parameter hematologis yang paling diabaikan dalam praktek klinis dan memiliki paling sedikit publikasi pada literatur medis. Perubahan PCT juga menyebabkan kondisi klinis seperti iskemia koroner, diabetes mellitus, TB paru dan penyakit inflmasi usus. ${ }^{11,12}$

\section{Bahan dan Metode}

\section{Rancangan Penelitian}

Penelitian ini merupakan penelitian cross sectional untuk mengetahui nilai diagnosis dan prognosis jumlah dan index trombosit pada sepsis neonatorum.

\section{Subjek Penelitian}

Subjek penelitian adalah semua penderita sepsis neonatorum yang masuk ke Ruang Perinatologi pada bulan Februari 2016-Juli 2016 yang memenuhi kriteria inklusi (usia 0-28 hari, memiliki data klinis dan laboratorium dan kriteria eksklusi (Idiopatik trombositopenia purpura, bayi dengan kelainan kongenital dan data rekam medis dan laboratorium yang tidak lengkap). Data diambil dari rekam medis setelah mendapat ijin dari Komisi Etik Penelitian RSU Saiful Anwar Malang.

Analisis Data

Data dilakukan uji normalitas Kolmogorov-Smirnov, yang dilanjutkan uji homogenitas menggunakan uji varians (Levene's test) dan independent sample $t$ test. ${ }^{13}$ Nilai diagnostik dan prognosis yang terdiri dari sensitivitas, spesifisitas, nilai duga positif, nilai duga negatif, rasio kemungkinan postif, rasio kemungkinan negatif, dan akurasi dihitung menggunakan kurva ROC (Receiver Operating Characteristic), kemudian ditentukan nilai cut off baik berdasarkan kurva ROC maupun membandingkan dengan penelitian lain. ${ }^{14}$

\section{Hasil}

Berdasarkan data sekunder, didapatkan 48 subjek yang memenuhi kriteria inklusi, dengan sebaran 36 subjek yang terdiagnosis sepsis neonatorum. Distribusi subjek dapat dilihat pada Tabel 1.

Tabel 1. Karakteristik subjek penelitian

\begin{tabular}{lllll}
\hline Derajat Sepsis & & $\mathrm{N}$ & Mean & Std. Deviation \\
\hline Trombosit & Sepsis & 36 & 198.75 & 86.114 \\
& Non Sepsis & 12 & 119.50 & 79.280 \\
MPV & Sepsis & 36 & 11.0917 & 1.29071 \\
& Non Sepsis & 12 & 10.0242 & .72131 \\
PCT & Sepsis & 36 & .2411 & .10733 \\
& Non Sepsis & 12 & .3342 & .21352 \\
Leukosit & Sepsis & 36 & 13.6119 & 10.87642 \\
& Non Sepsis & 12 & 18.1225 & 12.50848 \\
Kreatinin & Sepsis & 36 & 1.1689 & .87615 \\
& Non Sepsis & 12 & .6133 & .27727 \\
RR & Sepsis & 36 & 63.69 & 11.453 \\
& Non Sepsis & 12 & 73.67 & 33.170 \\
Suhu & Sepsis & 36 & 37.1111 & 1.41820 \\
& Non Sepsis & 12 & 36.7333 & .93550 \\
BB & Sepsis & 36 & 2275.71 & 817.110 \\
& Non Sepsis & 12 & 2494.67 & 702.408 \\
HR & Sepsis & 36 & 146.78 & 29.150 \\
& Non Sepsis & 12 & 142.83 & 33.962 \\
Usia & Sepsis & 36 & 10.06 & 7.749 \\
\hline
\end{tabular}




$\begin{array}{llll}\text { Non Sepsis } & 12 & 7.25 & 4.975\end{array}$

Tabel 2. Nilai diagnosis jumlah dan index trombosit

\begin{tabular}{|c|c|c|c|c|c|}
\hline & & & \multicolumn{2}{|c|}{ Diagnosis } & \multirow[t]{2}{*}{ Total } \\
\hline & & & Positif & Negatif & \\
\hline \multirow[t]{8}{*}{ Trombosit } & \multirow[t]{4}{*}{ Abnormal } & Count & 3 & 5 & 8 \\
\hline & & \%within Trombosit & $37,5 \%$ & $62,5 \%$ & $100,0 \%$ \\
\hline & & \%within Diagnosis & $10,7 \%$ & $25,0 \%$ & $16,7 \%$ \\
\hline & & $\%$ of total & $6,3 \%$ & $10,4 \%$ & $16,7 \%$ \\
\hline & \multirow[t]{4}{*}{ Normal } & Count & 25 & 15 & 40 \\
\hline & & \%within Trombosit & $62,5 \%$ & $37,5 \%$ & $100,0 \%$ \\
\hline & & \%within Diagnosis & $89,3 \%$ & $75,0 \%$ & $83,3 \%$ \\
\hline & & $\%$ of total & $52,1 \%$ & $31,3 \%$ & $83,3 \%$ \\
\hline \multirow[t]{4}{*}{ Total } & & Count & 28 & 20 & 48 \\
\hline & & \%within Trombosit & $58,3 \%$ & $41,7 \%$ & $100,0 \%$ \\
\hline & & \%within Diagnosis & $100,0 \%$ & $100,0 \%$ & $100,0 \%$ \\
\hline & & $\%$ of total & $58,3 \%$ & $41,7 \%$ & $100,0 \%$ \\
\hline
\end{tabular}

ROC Curve

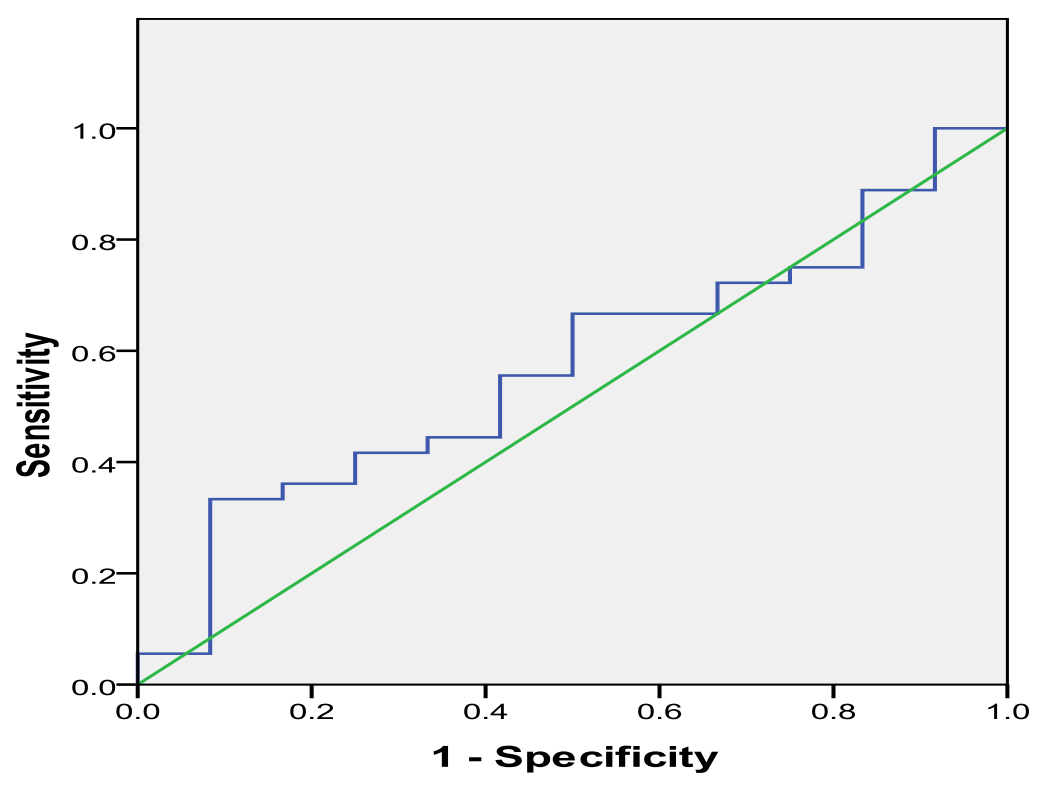

Gambar 1. Kurva ROC untuk jumlah trombosit

Nilai diagnostik trombosit untuk kelompok sepsis dan nonsepsis yaitu sensitivitas $89,3 \%$, spesifisitas $75 \%$, nilai duga positif $62,3 \%$, nilai duga negatif $25 \%$, rasio kemungkinan positif 0,93 , rasio kemungkinan negatif 1,17 , dan akurasi $25,10 \%$.
Didapatkan nilai diagnostis MPV untuk sepsis neonatorum yaitu sensitivitas $10,7 \%$, spesifisitas $25 \%$, nilai duga positif $37,5 \%$, nilai duga negatif $25 \%$, rasio kemungkinan positif 0,51 , rasio kemungkinan negatif 1,94 dan akurasi3,31\%. 
Selanjutnya dilakukan penilaian prognosis berdasarkan outcome penderita. Hasil analisis kurva ROC (Gambar 1) pemeriksaan trombosit berdasarkan hasil outcome penderita sepsis adalah nilai AUC trombosit adalah $57,2 \%$ dengan $95 \%$ confidence interval adalah $39,3 \%-75,1 \%$. Nilai AUC $57,2 \%$ termasuk nilai yang sangat lemah.

Pada Gambar 2 menunjukkan kurva titik potong berdasarkan ROC. Hasil penelitian menunjukkan bahwa kurva berpotongan di antara angka 22.000-29.000. Akan tetapi jumlah trombosit yang direkomendasikan sebagai cut off pada penelitian ini adalah
$<16.000 /$ uL, dan diperoleh nilai sensitifitas $55,6 \%$ dan spesifisitas $58,3 \%$.

Selanjutnya dilakukan analisis ROC untuk MPV. Nilai AUC pemeriksaan MPV adalah 33,2\%, dengan 95\% confidence interval adalah $16 \%-50,4 \%$. Nilai AUC $33,2 \%$ termasuk nilai yang sangat lemah. Selanjutnya dilakukan penentuan cut off sesuai analisis ROC.Titik potong yang didapatkan untuk MPV adalah 13-19 fl, sehingga kadar MPV ditentukan berdasarkan penelitian lain yaitu 10,35fl (Gambar 4). Bila menggunakan nilai 10,35 maka MPV mempunyai sensitivitas $33,3 \%$ dan spesifisitas $33,3 \%$ untuk diagnosa sepsis neonatorum.

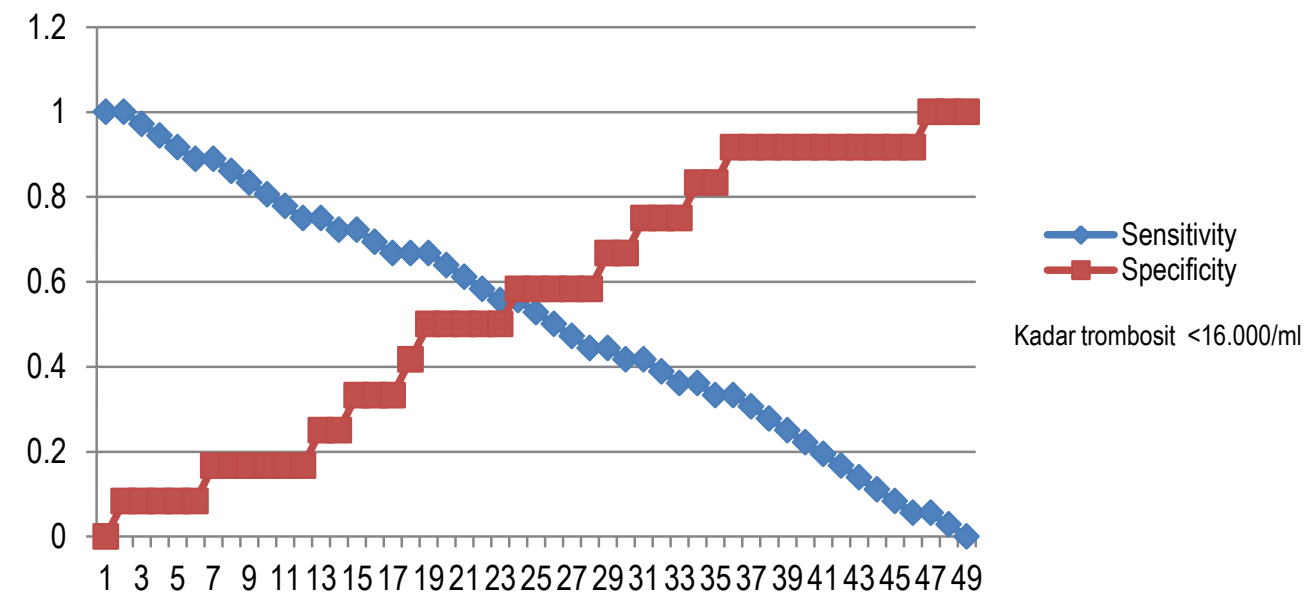

Gambar 2. Kurva titik potong berdasarkan ROC untuk jumlah trombosit. 


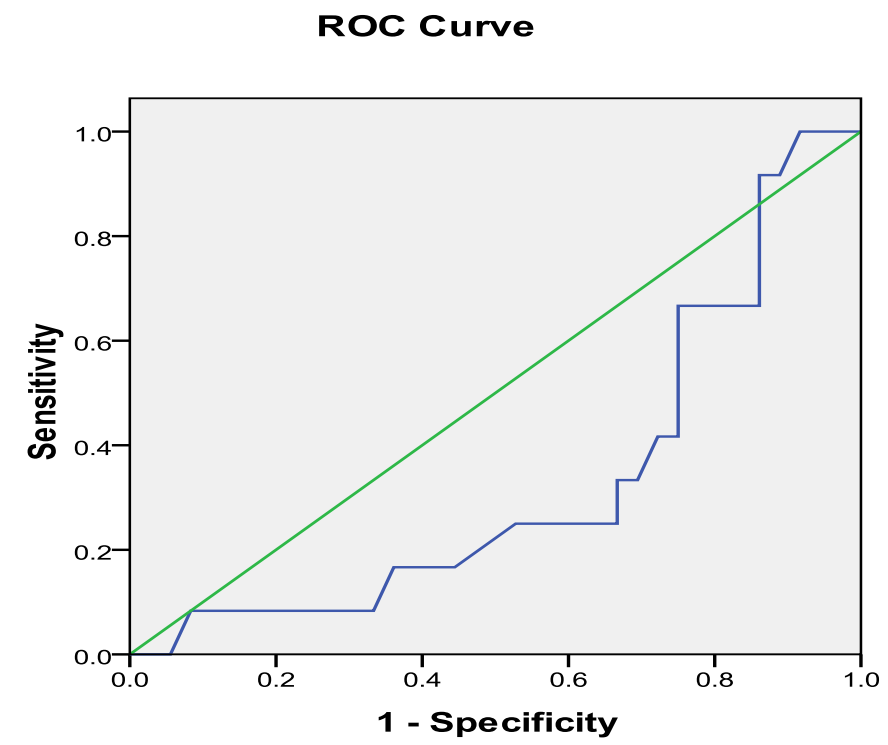

Diagonal segments are produced by ties.

Gambar 3. Hasil analisis ROC untuk variabel MPV.

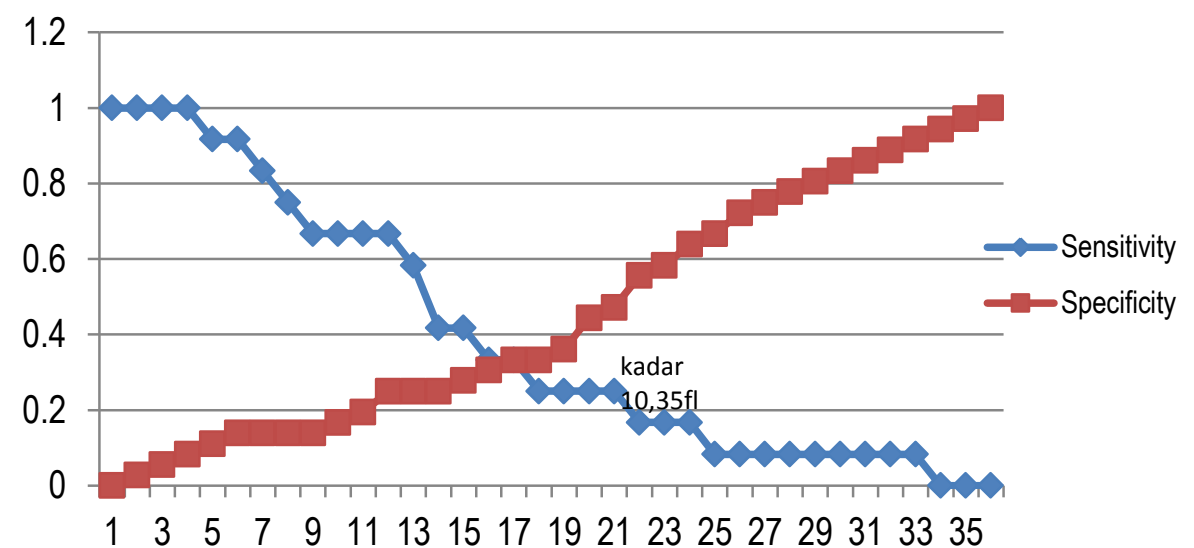

Gambar 5. Kadar MPV

\section{Pembahasan}

Pada penelitian ini didapatkan sebanyak $75 \%$ subjek didiagnosa sepsis secara klinis. Dari kedua kelompok sepsis dan nonsepsis didapatkan lebih banyak yang berjenis kelamin laki-laki. Namun, secara statistik menyatakan tidak ada perbedaan bermakna antara kelompok sepsis dan nonsepsis untuk jenis kelamin. Hal ini sesuai dengan penelitian di RSCM Jakarta yang didapatkan rasio sepsis neonatorum, seperti di RSUP Sanglah Denpasar didapatkan 56,8\% laki-laki dari 125 pasien neonatus sepsis yang dirawat, dan penelitian di Pakistan ditemukan $63,4 \%$ dari 112 sepsis neonatorum berjenis kelamin laki-laki. Sebuah hipotesis menjelaskan perbedaan ini karena faktorfaktor yang mengatur sintesis imunoglobulin mungkin pada kromosom $\mathrm{X}$, oleh karena itu 
kehadiran 2 kromosom pada perempuan menghasilkan fungsi pertahanan terhadap infeksi lebih besar. ${ }^{15}$

Trombosit adalah fragmen sitoplasmik tanpa inti berdiameter 2-4 mm yang berasal dari megakariosit. Kadar trombosit dalam tubuh dapat meningkat jika terjadi infeksi. Namun, penyakit infeksi terbanyak adalah infeksi sistem respiratori. Sebaliknya kadar trombosit dapat menurun misalnya pada saat terinfeksi berat. Pada kondisi sepsis neonatorum sering terjadi trombositopenia karena hipoplasia megakariosit, penurunan produksi trombosit, peningkatan penghancuran trombosit akibat splenomegali dan retikuloendotelial dan koagulasi intravaskuler diseminata, sedangkan trombositosis penyebab terbanyaknya adalah infeksi respiratori. Nilai diagnostik yang didapatkan yaitu sensitivitas $89,3 \%$, spesifisitas $75 \%$, nilai duga positif $62,3 \%$, nilai duga negatif $25 \%$, rasio kemungkinan positif 0,93 , rasio kemungkinan negatif 1,17 , dan akurasi $25,10 \%$.

Hasil analisis statistik menunjukkan bahwa jumlah trombosit sensitif, sehingga dapat digunakan untuk skrining maupun diagnosis sepsis. Namun nilai spesifisitas yang lebih rendah menunjukkan bahwa jumlah trombosit kurang berguna dalam menyingkirkan diagnosis sepsis. Sistem hematologi memegang peranan penting dalam penghantaran oksigen, pembuangan karbondioksida, hemostasis, dan pertahanan diri terhadap pathogen. Gangguan hematologi pada sepsis dapat sering dihubungkan dengan terjadinya morbiditas dan mortalitas pada pasien sepsis. ${ }^{16,17}$

Mean platelet volume mengukur ukuran trombosit yang beredar dalam darah perifer. MPV meningkat secara signifikan pada neonatus dengan sepsis pada hari kedua atau ketiga kehidupan. Kadar normal MPV adalah 7,5fl. Nilai sensitivitas yang rendah menunjukkan MPV. Nilai MPV abnormal ditemukan pada $62,5 \%$ subjek yang memiliki hasil kultur positif dan 37,5\% pada subjek yang memiliki hasil kultur negatif. Menurut Destugue dkk dan Vander Lelie dkk, menyatakan bahwa terdapat peningkatan MPV pada pasien sepsis dan syok septic. MPV dapat digunakan sebagai prediktor pemulihan trombositopenia yang disebabkan oleh supresi sumsum tulang pada sepsis, dapat mendeteksi gangguan trombosit lebih awal walaupun jumlah trombosit masih normal, serta dapat membedakan penyebab trombositopenia. Connor dkk., menemukan bahwa MPV dapat digunakan sebagai pemeriksaan tambahan untuk mendiagnosis sepsis neonatorum dengan bakteri stafilokokus koagulase negatif.

Cho SY dkk melaporkan bahwa MPV meningkat seiring dengan peningkatan procalsitonin $>1,0 \mathrm{ng} / \mathrm{mL}$ walaupun secara statistik tidak signifikan. Hal ini juga menunjukkan bahwa peningkatan MPV mengindikasikan adanya proinflamasi dan kondisi trombosis yang melibatkan sejumlah mediator inflamasi, sitokin dan disfungsi endotel. Eberhardt A dkk melaporkan penelitian yang melibatkan 183 pasien sepsis bahwa MPV mempunyai korelasi positif yang signifikan dengan terjadinya bakterimia dan kematian sehingga MPV dapat digunakan sebagai biomarker untuk menilai beratnya derajat sepsis yaitu semakin tinggi nilai MPV maka prognosisnya semakin buruk. Kukukardali Y dkk juga menemukan korelasi positif yang signifikan antara MPV dan skor APACHE dalam menilai beratnya sepsis $(r=$ 0,34 ), namun tidak didapati korelasi yang signifikan antara MPV dengan kematian pada pasien sepsis yang dirawat di ICU. ${ }^{17,18}$

Trombosit dihasilkan dalam sumsum tulang melalui fragmentasi sitoplasma megakariosit. Tanpa trombosit, dapat terjadi kebocoran darah spontan melalui pembuluh darah kecil. Analisis kurva ROC trombosit menunjukkan nilai AUC sebesar 57,2\% (95\% confidence interval 39,3\%-75,1\%), $p=0,460$. Secara statistik nilai AUC tergolong sangat 
lemah. Morbiditas bayi dengan BBLR di ruang perinatologi RSUD Arifin Achmad Pekanbaru mayoritas memiliki morbiditas yang kompleks. Definisi kompleks merupakan penggabungan atau kombinasi dari beberapa gejala. Gejalagejala yang ditemukan meliputi anemia, trombositopenia, leukopenia, ikterik (hiperbilirubinemia), hipoglikemia, hipokalsemia, hipetrermi, dan gangguan pada sistem perkemihan. ${ }^{18}$

Analisis kurva ROC terhadap MPV menujukkan nilai AUC sebesar 33,2\% (95\% confidence interval 16\%-50,4\%), $p=0,084$. Secara statistik nilai AUC $33,2 \%$ tergolong sangat lemah. Ukuran MPV merupakan indikasi ukuran trombosit yang beredar dalam darah perifer, maka peningkatan MPV merupakan terjadinya peningkatan produksi trombosit, mungkin sebagai kompensasi terhadap percepatan destruksi platelet. MPV menunjukkan terjadinya infeksi invasif atau infeksi yang tidak responsif dengan pemberian antibiotik, sehingga menimbulkan mortalitas yang tinggi pada sepsis. ${ }^{18}$

\section{Kesimpulan}

Pada penelitian ini didapatkan nilai diagnostik trombosit dengan cut off $<16.000 / \mu \mathrm{L}$ memiliki nilai sensitivitas tertinggi namun tidak spesifik untuk mendiagnosis sepsis neonatorum (sensitivitas 89,3\% dan spesifisitas $75 \%$ ). Nilai diagnostik mean platelet volume (MPV) tidak sensitif namun spesifik untuk diagnosis sepsis neonatorum (sensitivitas 10,7\% dan spesifisitas 25\%). Nilai prognostik jumlah trombosit dan mean platelet volume (MPV) pada sepsis neonatorum adalah lemah.

\section{Saran}

1. Penelitian lebih lanjut mengenai trombosit dan komponennya untuk diagnosa dan prognosa sepsis neonatorum dengan jumlah sampel yang lebih besar.
2. Penelitian lebih lanjut menggunakan variabel lain yang lebih baik seperti penggunaan sitokin proinflamasi untuk menentukan diagnosis dan prognosis sepsis neonatorum.

\section{Daftar Pustaka}

1. Wilar R, Antolis $Y$, Tatura SNN, Gunawan S. 2010. JumlahTrombosit dan Mean Platelet Volume sebagai Faktor Prognosis pada Sepsis Neonatorum. Sari Pediatri. 2010; 12(1):53-57.

2. Roeslani RD, Amir Idham, Nasrulloh MH, Suryani. Penelitian Awal: Faktor Risiko pada Sepsis Neonatorum Awitan Dini. Sari Pediatri. 2013; 14(6):363-368.

3. Answer SK dan Mustafa S. Rapid Identification of Neonatal Sepsis. J Pak Med Assoc. 2000; 50(3):94-98.

4. Reslina Ade.N, Fatmawati, Wisnumurti DA. Gambaran Rasio Neutrofi IImatur/ Neutrofil Total (Rasio I/T) pada Tersangka Sepsis Neunatorum yang Dirawat di Instalasi Perawatan Neonatus RSUD Arifin Achmad Provinsi Riau. JOM FK. 2015; 2(2):1-10.

5. Sofwan R, Suhelda $S$, Lembar $S$. Prokalsitonin sebagai kandidat petanda inflamasi pada Sepsis Neonatorum. Damianus Journal of Medicine. 2010; 9(1): 34-44.

6. Analis R. Makalah Trombosit. 2012.

7. Depkes. Penatalaksanaan Sepsis Neonatorum. Jakarta. 2007.

8. Hoffbrand AV, Pettit JE, Moss PAH. Essential Haematology. Setiawan Lyana (Penerjemah). Jakarta: EGC. 2005. HIm. 221-228.

9. Setiati $S$, Idrus $A$, Sudoyo AW, Simadibrata M, Setiyohadi B, Syam AF (Editor). Buku Ajar IImu Penyakit Dalam. Jilid ke-5. Jakarta: Interna Publishing. 2014.

10. Gunawan S, Sutanto FC, Tatura SNN, Mantik MFJ. Platelet Distribution Width 
dan Mean Platelet Volume: Hubungan dengan derajat Penyakit Demam Berdarah Dengue. Sari Pediatri. 2010; 12(2):74-77.

11. Agoropoulou KK, Evdoridou I, Sarafidis K, Diamanti E, Soubassi V, Drossou V. Thrombocytopenia and Platelet Indices in Septic Neonates. (Abstract). Haematologica. 2010.

12. Leal -Santos FA, Silva SBR, Crepaldi NP, Nery AF, Martin TOG, Junior-Alves ER, Fontes CJF. Altered Platelet Indices as Potential Markers of Severe and Complicated Malaria Caused By Plasmodium vivax: A Cross-Sectional Descriptive Study. Malaria Journal. 2013; 12:462. doi: 10.1186/1475-2875-12-462.

13. Dahlan SM. Statistik Untuk Kedokteran dan Kesehatan. Edisi ke-6. 2014. HIm. 225-234.
14. Dahlan M, Sopiyudin. Statistika Untuk Kedokteran dan Kesehatan. Jakarta: Arkans. 2004.

15. Putra PJ. Insidendan Faktor-Faktor yang Berhubungan dengan Sepsis Neonatus di RSUP Sanglah Denpasar. Sari Pediatri. 2012; 14(3):205-210.

16. Masihor JJG, Mantik MFJ, Memah M, Mongan AE. Hubungan Jumlah Trombosit dan Jumlah Leukosit pada Pasien Anak Demam Berdarah Dengue. Jurnal eBiomedik. 2013; 1(1):391-395.

17. Hill-McGraw. Harrison's Principles of Internal Medicine 13/E,Asdie HA. EGC: Jakarta. 2014. HIm. 571-576.

18. Bessman JD, Gilmer PR, Gardner FH. Use of Mean Platelet Volume Improves Detection of Platelet Disorders. Blood Cells. 1985; 11:127-35. 